$\begin{gathered}\text { Journal of Business Management and } \\ \text { Economic Research }\end{gathered}$
2019, 3 (2): 26-41 DOI: 10.29226/TR1001.2019.107
Journal Homepage: https://www.jobmer.org

\title{
The Profitability Analysis of Islamic (Sukuk) vs. Conventional Financing: an Empirical Analysis
}

\author{
Arshad Ullah Jadoon \\ School Of Economics, Northeast Normal University, Changchun, China \\ Arshadjadoon22@gmail.com \\ Yangda Guang \\ School Of Economics, Northeast Normal University, Changchun, China \\ Sajjad Ali \\ Assistant Professor, Higher Education Department Peshawar Pakistan
}

\begin{abstract}
Over the last decade, Islamic Financials (Sukuk) emerged as a pioneering capital market instrument. One of the fundamental reasons for the emerging demand of Islamic Financing (Sukuk) includes its adherence to the finance in accordance to the Islamic values, avoiding Riba, which is the generation of money from money such as usury or interest. Sukuk issues havenotably proliferated, which fuels the debate regarding the between the conventional and the Islamic finance. To investigate the impact of Islamic and Conventional Financials on shareholders' wealth, this study takes the profitability ratios (including ROA, ROE, ROCE, and NPM) of 15 companies issuing Islamic Financials and 15 companies issuing Conventional Financials from the period between 2010 and 2017 and compares the profitability of both ffinancials. The findings reveal the Islamic Financials(Sukuk) to be a significantly high source of profitability for a company along with the other clients' catchy determinants such as religious principles, sharia-compliant instruments, and interest (Riba) free financing. The paper provide evidence that companies are recommended to pay more attention to Islamic Sukuk in order to grab the attention of customers. Furthermore, the Islamic Financials (Sukuk) offers other instruments to catch the customers' attention such as religious principles, shariacompliant instruments, and interest (Riba) free financing. From this perspective, the mentioned determinants fulfil the religious needs of customers.
\end{abstract}

Keywords: Islamic finance, Islamic Sukuk, profitability, sharia-compliant instruments

JEL Codes: G21, G23. 
Journal of Business Management and Economic Research, vol.3, issue.2, pp.26-41

\section{Introduction}

Islamic finance, a term that gained momentum since last two decades requires adherence to Islamic laws and formation of sharia-compliant structures. All the products or services under these structures are subject to sharia compliance. According to Uusmani and Taqi 'Usmani (2002), Islamic finance is a system, which is based on the Islamic law while, Conventional finance is based on manmade law. The purpose of Islamic Financing is to establish justice and equality in the society while Conventional finance being an ethic-neutral system is not much helpful to achieve this objective because money keeps circulating in a few hands only. Transactions involving Riba (interest) and speculations are prohibited and no guaranteed return is offered to investors; rather profit are generated on business risk-sharing basis. After confirming to sharia standards, Islamic financial institutions can produce the instruments that can replace the conventional interest-bearing speculative equity, derivatives and mortgages schemes of financing. These sharia-compliant instruments would make the transfer of an asset in a systematic way from lender to the borrower. For instance, Sidlo (2017) states, "regulations are necessary in the fiscal field, as certain Islamic structures (such as murabaha) can potentially result in multiple tax duties being applied on the transfer of assets" (p. 12). Having this as a reference, a lot many Islamic financial instruments are designed in which lending transactions are backed by real assets and credit participation involves business risk instead of guaranteed return (Jobst, 2007).

\subsection{Background of the Study}

One of the developments in the Islamic financial industry is the introduction of Sukuk. Sukuk is the plural form of word Suk. The Accounting and Auditing Organisation defines the Sukuk as "equal value certificate of undivided shares provided in possession of assets tangible in nature, Services and usufruct or in possession of asset pertaining to a particular project or activity entailing especial investment" (AAOIFI 2008, p. 307).Sukuk is a novel specification of debt when probing into its capabilities for the provision of funds and diversity in this area. They can be viewed in light of regular bonds but since these come under the head of Islamic financial instrument so compliance to sharia is necessary. The riskiness of Sukuk is similar to that of the bond as they depend on the financial credibility of the issuer. The holders of these certificates enjoy an exclusive benefit generating ownership in the asset underlying the transaction. They benefit from both ends firstly, from the

profits derived from these assets and secondly, from the proceeds of its realization. At some places, 
Journal of Business Management and Economic Research, vol.3, issue.2, pp.26-41

they are also claimed to be a developmental tool rather having being classified as a financial tool.

\subsection{Problem Statement}

The local market lacks a portfolio of Islamic financial instruments that could be utilized by nonIslamic profitable institutions. A step into the local financial market gives an impression to the investors that they are limited to few choices when it comes to sharia-compliant securities that could offer better profitability. An environment whereby the ultimate focus is laid on Murabaha, Ijara, and Wakala investment. As financial instruments based on sharia-compliant laws, Sukuk can be considered as a unique addition to Islamic financing tools that can address the concern of deficiency of such tools in local markets. In addition to the case of securitization, whereby a heated up debate always stands on its sanctity among religious figures (Al-Salem, 2009). Therefore, this research bases its focus to establish the profitability comparison of companies offering Sukuk Certificates and others that utilize conventional financing.

\subsection{Purpose of the Study}

Islamic finance is an emerging field with a considerable number of research studies focusing on how Islamic finance offer solutions to traditional and modern financial markets. For a viable development of Islamic finance, Islamic capital market (ICM) is crucial. The main goal of ICM is to allocate and mobilize resources efficiently. This realistic goal can be accomplished through the development of real sector financing. From a different perspective, ICM can perform the task of liquidity management through sharia-compliant money market operation in the Islamic financial industry. Management of liquidity is core to ICM in short run since it would provide sustainability in long run to Islamic financial institutions (IFI's) within the area of financial markets. Hence there exist dire need to innovate products that are complying the laws of sharia so that the concept of efficient and vibrant ICM could be materialized (Nazar, 2015). In this regards, Sukuk as a tool for operationalizing the concept of the sharia-based product plays a pivotal role in resource mobilization and smoothing liquidity in ICM. It is Islamic financial instrument with the enormous capability to provide a boost in economic growth of the country and significantly inculcate initiatives for development of real financial Sector. This research will further probe that role of Sukuk in profitability of its issuing forms by comparing the profitability of both Sukuk issuing firms and other traditional bond-issuing firms. Islamic Sukuk can also be an ideal offering for overall market integration of Islamic financial 
instruments entailing varying risk levels to satisfy the diversified need of investors. It would provide an opportunity to market growth since growth would no longer remain the function of institution size or borrowing capability rather its ability to securitize assets and issue Sukuk. Sukuk issue would increase growth prospects, financial returns and spread the risk arising from organizations deriving funds from a large number of lenders: those issuing Sukuk certificate rather allowing it to be borne by banks. Simply both the institution issuing Sukuk and the banks financing it would mark an increase in their credit ratings ( Al-Salem, 2009). Considering the increased benefit of Sukuk financing, this study builds the following research question:

\subsection{Research Question}

Which of the financing institutions (based on conventional bounds or Islamic Sukuk) is performing well in their respective domains in terms of profitability?

\section{Hypotheses}

H1: There is no difference between ROA of Sukuk Financing Institutions and interest-based financing schemes of conventional Financing Institutions

H2: There is no difference between ROE of Sukuk Financing Institutions and interest-based financing schemes conventional Financing Institutions

H3: There is no difference between ROCE of Sukuk Financing Institutions and interest-based financing schemes conventional Financing Institutions

H4: There is no difference between the Net profit Margin of Sukuk Financing Institutions and interest-based financing schemes conventional Financing Institutions

\section{Literature Review}

A large number of studies have been conducted to examine the difference between the efficiency of Conventional Banks (CBs) and Islamic Banks (IBs). From this perspective, some of the studies indicated no difference between the efficiency of IBs CBs, nevertheless, a significant number of studies shows that IBs are more efficient as compared to the CBs. On the other hand, some of the other studies suggest that IBs are not more efficient as compared to the CBs. According to the study conducted by Saiti, Bacha, and Masih (2016), a closer analysis of the performance of both types of financials shows certain regularity. For example, no considerable difference (or to some extent higher 
efficiency in the operations of IBs) is found between IBs and CBs if the pre-crisis period is examined (smaller ones and the big one). On the other hand, the efficiency of IBs is found as lower as compared to CBs if the period of crisis is examined.

Financials with the primary goal of maximizing the profits are generally considered as the most significant financial institutions in most of the countries. Arslan-Ayaydin, Bejaoui, Dorsman, and Shahzad (2016) noted that Islamic financials are in the efforts to be socially responsible while operating in accordance with religious principles such as prohibiting the use of interest and following the model of profit and loss sharing with their clients and thus generating more revenue. IBs and Islamic finance, in general, represent one of the fastest growing financial industries despite its relatively short history compared to CBs (Iqbal \& Mirakhor, 2011). Exploring the difference between the Islamic financing and Conventional financing, Arslan-Ayaydin, Bejaoui, Dorsman, \& Shahzad (2016) found that "Transactions in Islamic Finance (IF) are guided by ethical, moral, and social considerations. Moreover, according to IF money should be used to create social value. With regard to these point of views, IF aligns with Socially Responsible Investing (SRI), which refers to the combination of social, environmental and ethical requirements when making financial investment decisions" (p. 187). On the other hand, investments are exclusively focused on return and risk in conventional finance (CF); nevertheless, Islamic Finance and Socially Responsible Investing also have a social value component. Islamic banking is based on Islam's terms and conditions while Conventional banking (financing) is an un-ethical system whose main aim is to get more money in the form of interest. Islamic financing is becoming more and more popular across the world due to its policies but sometimes it may not support you (Bley \& Kuehn, 2004).

If an individual wants to get a loan for a bear shop/business, Islamic finance cannot help him, as it is an illegal business and one cannot get a loan for it. While conventional finance can give the desired loan and the loan taker is supposed to return it with interest (Hanif, 2011). Conducting a study to determine the risk determinants of liquidity risk between Islamic and Conventional banks, Waemustafa and Sukri (2016) found that money is a product and not the medium in the Conventional Financing, while real property is a product and money is just a medium of exchange in the Islamic Financing. Similarly, interest is charged on the basis of time (Interest can increase with the flow of time) in Conventional Financing, while profit is earned by exchanging goods and services in Islamic Financing. According to Samad (2004), "there is no major difference in performance 
Journal of Business Management and Economic Research, vol.3, issue.2, pp.26-41

between Islamic and conventional banks with respect to profitability and liquidity. However, the study finds that there exists a significant difference in credit performance" (p. 1). For instance, conventional financing does not share losses and the client is charged interest even in the case of loss. Nevertheless, Islamic financing shares the loss. In the same way, the government very easily obtains loans from Central Bank via Money Market Operations without initiating capital development procedure in the case of Conventional Financing. On the other hand, the government cannot gain loans from the Monetary Company without making sure the delivery of goods to National Investment fund in Islamic financing.

Conducting a study on the preferences of clients of Conventional and Islamic banks in Bahrain in order to choose a bank to patronize, Al-Ajmi, Abo Hussain, and Al-Saleh (2009) found, "Islamic religious belief and social responsibility are the two most important factors that determine bank selection. Cost-benefit is the third most important factor considered in bank selection; clients of conventional and Islamic banks share a number of motives, but they differ significantly on a few motives in relation to bank selection; and clients of Islamic banks are more familiar with the products/services that conform to the shari'a" (p. 1086). Money remains in a few hands that is why there is no real growth of money and society cannot build up well

Via Conventional financing. Nevertheless, real growth in the wealth of the people of the society takes place in Islamic financing, due to multiplier effect and real wealth goes into the ownership of a lot of hands. According to Mollah and Zaman (2015), the loan can be written off if the project fails in Conventional financing whereas it is transferred to any other organization in the Islamic financing if a project fails.

\subsection{Countries/Companies Using Islamic Financing}

All the Islamic countries are using Islamic financing/banking system. Besides them, Islamic banking is also popular in non-Muslim counties. For an example: India is a non-Muslim country and there is no existence of Islamic financing but after the orders of Indian Supreme Court, now there are many organizations which are running on the base of Islamic finance system (Derigs \& Marzban, 2008). A large number of banking systems were founded during the 1970s, to be claiming for the provision of Islamic Financing. These banks include the first private commercial bank in Dubai in 1975, in Sudan (Faisal Islamic Bank of Sudan) in 1977 and in Bahrain (Bahrain Islamic bank) in 1979 (Institute of 
Journal of Business Management and Economic Research, vol.3, issue.2, pp.26-41

Islamic Banking and Insurance, The Islamic Banker). Today, the world counts over 300 IBs in more than 70 countries. Besides the Muslim countries, they can be found in various countries such as Australia, the Bahamas, Denmark, France, Ireland, Luxembourg, Germany, the USA, Switzerland, the UK, as well as Albania and Bosnia and Herzegovina. The only Southeast Europe countries in which there are banks that operate on Islamic financial principles (Ali, 2014).

\subsection{Islamic and Conventional Finance in Asian Countries}

Agriculture is the heart of Bangladesh's economy and holds a significant stake in economic development. Around $85 \%$ of our total population directly or indirectly depends on agriculture (Miah \& Sharmeen, 2015).Different sectors of agriculture like as Cultivation of crops,Plantation, Agricultural Machineries and Implements, Agricultural Fertilizers and Pesticides, Livestock's and so on have developed because of bank financing in different forms. The average growth rate of financing and investment in agriculture, fishing and forestry is $165.60 \%$ and $89.50 \% \mathrm{f}$ o r Islamic and conventional banks respectively that specifies higher involvement of Islamic banks in agriculture, fishing and forestry. In an underdeveloped country like Bangladesh Small \& Cottage Industries play a major role in economic development (Rahman \& Banna, 2016). Under SME the following sectors like as dyeing and printing, sawmills, salt manufacturing and processing industries, plastic and plastic products, cosmetics, milk and milk products, jam, jelly, ice factories, wood and wood products \& light engineering are getting priority in bank lending and investment (Islam, Alam, \& Hossain, 2014). That contributes to reducing unemployment and encouraging new entrepreneurs. Conventional banks' participation is higher.

Beside above sectors, there are many other sectors (like the oil industry, infrastructure, transport etc.) in which Islamic and Conventional financing system help Bangladesh's economic development. Although Conventional Financing plays an important role according to the above data but statically, Islamic Financing is more social and helpful in economic growth. This can be easily understood by understanding the above comparison data (Islam, Alam, \& Hossain, 2014). Figure 1 compares the conventional bond and Islamic Sukuk. 
Figure 1: Conventional Bond vs. Suluk Source: Sonavane (2013)

\begin{tabular}{|c|c|c|}
\hline Criteria & Conventional bond & Islamic Sukuk \\
\hline $\begin{array}{l}\text { Nature of } \\
\text { security }\end{array}$ & Debt obligation & Share of ownership in asset/project \\
\hline $\begin{array}{l}\text { Nature of } \\
\text { investment }\end{array}$ & $\begin{array}{l}\text { To finance any type of } \\
\text { business if it complies with } \\
\text { local law }\end{array}$ & $\begin{array}{l}\text { Asset/project has to be Shariah compliant } \\
\text { (e.g. investing in weapon producing } \\
\text { company is not allowed) }\end{array}$ \\
\hline Issue price & Based on rating of the issuer & Based on market value of asset/project \\
\hline $\begin{array}{l}\text { Return on } \\
\text { investment }\end{array}$ & Regular interest payments & Share of profits derived from asset/project \\
\hline Risks & $\begin{array}{l}\text { Interest rates fluctuations, } \\
\text { default risk }\end{array}$ & Risk of sharing a loss, default risk \\
\hline
\end{tabular}

\section{Methodology}

Since this research concentrates on the readily available data in the company's annual reports, it is a secondary data research. Different companies' reports are accessed from the respective websites and data are collected from its published financials statements therein. According to Boslaugh (2007), secondary data is collected by an individual who is not the actual user of the gathered data. For instance, information collected by government departments, censuses, data that was initially collected for other research purposes, and organizational records are a few examples of the secondary data set when such data set are used by a researcher for the secondary purpose.

\subsection{Sample and Frequency}

The profitability ratios of 15 companies issuing Sukuk financials and 15 companies issuing Conventional financials, currently functional in Pakistan, were planned to gather from the period between 2010 and 2017. The data gathered was annual in nature; therefore, the number of observations for each variable was supposed to be 172 for both of the financings, as data for 15 companies issuing Sukuk financials and 15 companies issuing Conventional financials are crosssectional units for about 8 years were analyzed. Nevertheless, while compiling the secondary data 
from the annual financial statements, that reflects the operations of a business for an analysis of its performance (Penman, 2016), of the each selected company, it was found that some of the profitability ratios were missing. From this perspective, some of the companies with the missing data were deselected. In the same way, the duration of the years was to be reconsidered to include the maximum number of companies. The detail of included companies and the selected time period is mentioned in Table 1 in the descriptive analysis.

\subsubsection{Variables}

Since the analysis would be conducted on the profitability ratios, four accustomed profitability ratios, i.e. Return on Assets (ROA), Return on Equity (ROE), Return on Capital Employed (ROCE) and Net Profit Margin (NPM) were chosen for the analysis. From this perspective, ROA indicates the profitability of a company in relation to its total assets. With the calculation of ROA, an investor, manager, or analyst can have the idea about the efficiency of company's management using its assets to generate earnings (Heikal, Khaddafi, \& Ummah, 2014). ROE, also known as return on net worth, is used to measure the financial performance of a company. According to them, "a rising ROE suggests that a company is increasing its ability to generate profit without needing as much capital". The financial ratio ROCE measures the profitability and efficiency of a company in line with its employed capital. Defining the NPM, Bragg (2017) states, “Net profit margin is the percentage of revenue left after all expenses have been deducted from sales. The measurement reveals the amount of profit that a business can extract from its total sales. The net sales part of the equation is gross sales minus all sales deductions, such as sales allowances" (p.n.d). Following are the formulas used to calculate each financial ratio:

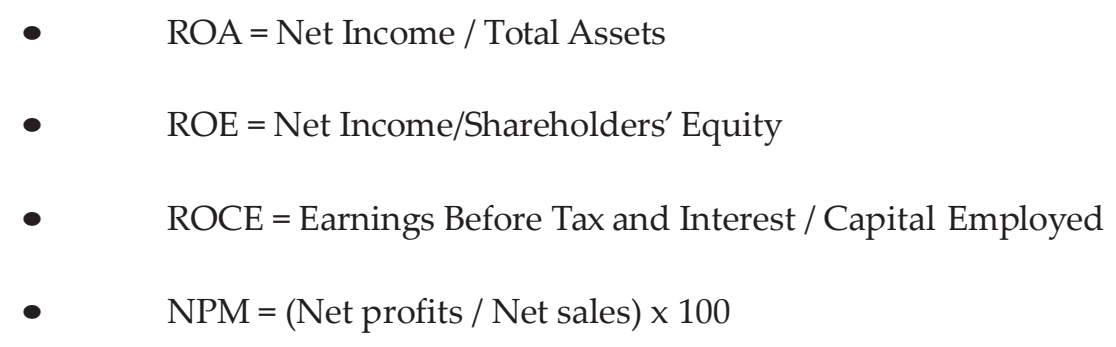

\subsubsection{Data Analysis}

The analysis of the gathered data is based on two techniques, descriptive and inferential. The descriptive analysis of the gathered data was accomplished by employing descriptive statistics to 
describe the characteristics of the selected companies. On the other hand, an independent sample Ttest was applied to analyze (the inferential analysis) the profitability difference in institutions issuing Sukuk and those that are working with conventional ways of financing. Independent sample T-test was appropriate for the study since the study was comparative in nature and its inferences were based on mean comparisons. Furthermore, the stated hypotheses were justified based on the inferential analysis.

\section{Results and findings}

\subsection{Descriptive Statistics}

Table 1 describes the characteristics of the selected companies. Since the available data was missing in the published Financial Statements of the selected companies, the data of 6 years (between 2010 and 2015) from 11 companies providing Islamic Financials (Sukuk) and 11 companies providing Conventional Financials was included in the data analysis. From this perspective, $\mathrm{N}=66$ reveals the total number of observation from each of the Conventional Financials (6 years' data of 11 companies) and Islamic Financials (6 years' data of 11 companies).

Table 1: Descriptive Statistics

\begin{tabular}{|l|l|l|l|l|l|}
\hline \multicolumn{2}{|l|}{ Group Statistics } \\
\hline ROA & Conventional Financials & 66 & 2.58 & 8.35 & 1.028 \\
\hline \multirow{2}{*}{ ROE } & Sukuk Financials & 66 & 5.35 & 6.09 & .75 \\
\cline { 2 - 7 } & Sukuk Financials & 66 & 19.15 & 38.16 & 4.69 \\
\hline ROCE & Conventional Financials & 66 & 8.49 & 17.40 & 2.14 \\
\cline { 2 - 7 } & Sukuk Financials & 66 & 13.19 & 8.79 & 1.08 \\
\hline NPM & Conventional Financials & 66 & -15.56 & 11.78 & 1.45 \\
\hline
\end{tabular}


Journal of Business Management and Economic Research, vol.3, issue.2, pp.26-41

\begin{tabular}{|l|l|l|l|l|l|}
\hline Sukuk Financials & 66 & 21.35 & 23.43 & 2.88 \\
\hline
\end{tabular}

It can be well observed from the Group Statistics in Table 1 that a considerably large difference exists in the financial profitability indicators of both firms. The institutions using conventional ways of financing are having low profitability as compared to that using Sukuk mode of financing. despite profitability, the risk involved with these institutions is also high since their standard deviation is also comparatively high except for the return on capital employed thereby Sukuk issuing institutions are fluctuating more.

\subsection{Comparing the Profitability of Conventional and IslamicFinancials}

Table 2 compares the profitability of Conventional and Islamic Financials if the existing difference is significant.

Table 2: Independent Samples Test

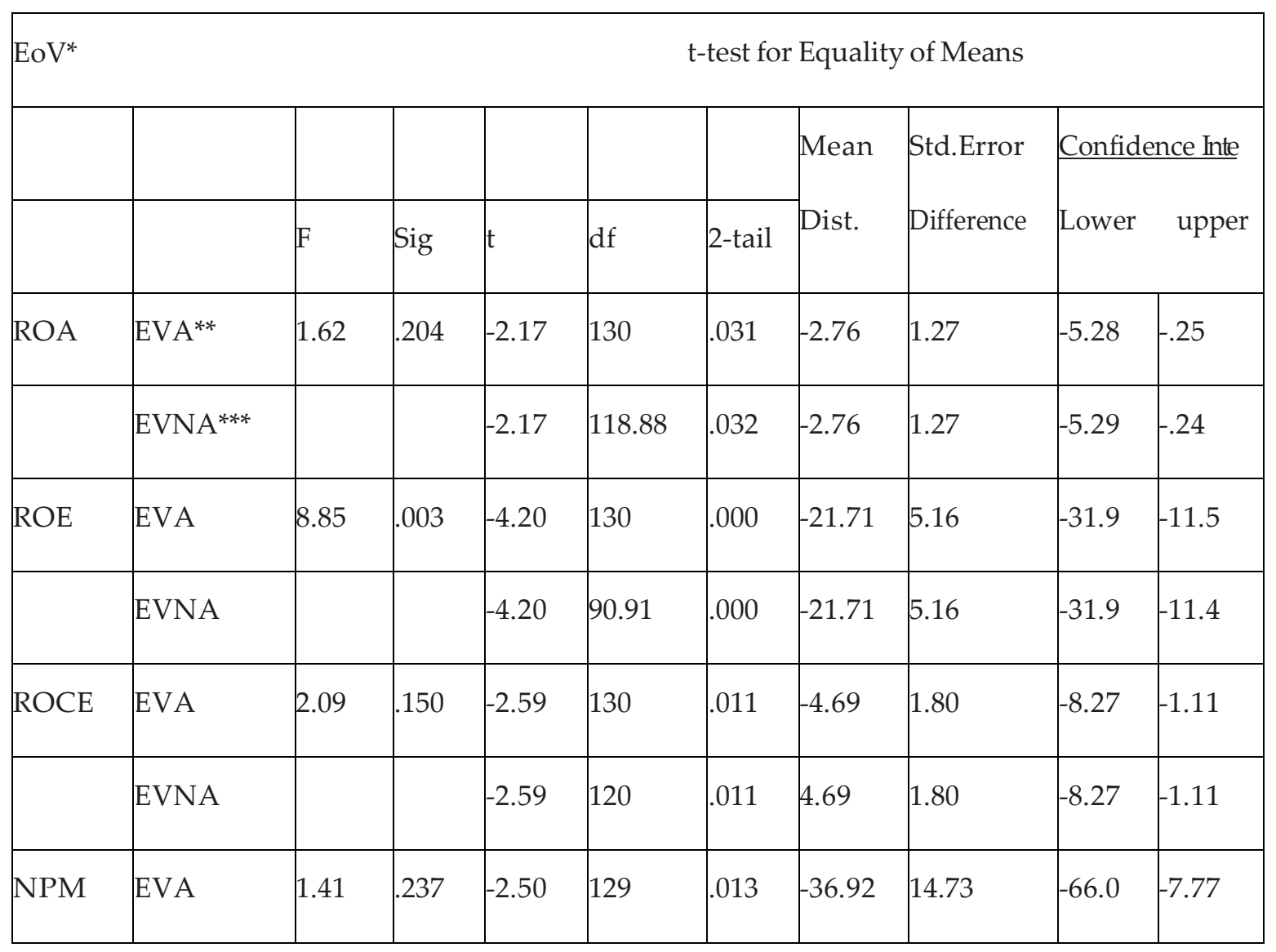




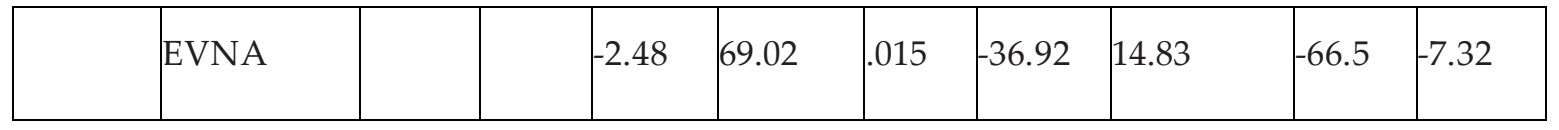

* Equality of Variances

${ }^{*}$ Equal variances assumed

*** Equal variances not assumed

With respect to the results of ROA, first, the null hypothesis of the Levene test that equal variances are assumed $(\mathrm{p}>0.1, \mathrm{~F}=1.627)$ is to be retained. Now in alignment with the first row of equal variance assumed the first hypothesis can be rejected and can be concluded that there exists a statistically significant difference in the average ROA of Sukuk financing and conventional financing institution $\mathrm{t}(130)=-2.17, \mathrm{p}<05$. The average mean difference between both is $(-2.76)$ indicating that Sukuk institutions ROA is greater than conventional ones. In the case of RoE, we would reject the null hypothesis of Levens test hence ending up with following the second row ( $p<0.05, F=8.85$ ). According to the statistics available, $\mathrm{p}=.000, \mathrm{t}(118.889)=-4.20$ we can again reject our null hypothesis and can mark that there exists a significant difference in average ROE of Sukuk financing and conventional financing institutions. The Sukuk financing institutions supersede in this regards since the average mean difference is (21.71). ROCE and NPM also indicate comparative results, after retaining its null hypothesis for levels test, it could be observed that there exist do exist a statistically significant difference in this profitability indicator of Sukuk financing and conventional institution. This makes us reject our third $\{t(130)=-2.595, p<0.05\}$ and forth $\{t(129)=-2.506, p<$ $0.05\}$ hypothesis.

\subsection{Hypotheses Assessment Summary}

Table 3 presents the status of hypotheses along with their $t$ and $p$ values.

Table 3: Hypothesis Assessment Summary

\begin{tabular}{|l|l|l|l|}
\hline No & Hypotheses & Status & Criteria \\
\hline 1 & $\begin{array}{l}\text { There is no difference between ROA of Sukuk Financing Reject } \\
\text { Institutions and interest-based financing schemes of } \\
\text { conventional Financing Institutions }\end{array}$ & $t=-2.175, \mathrm{p}<05$ \\
\hline
\end{tabular}


Journal of Business Management and Economic Research, vol.3, issue.2, pp.26-41

\begin{tabular}{|l|l|l|l|}
\hline 2 & $\begin{array}{l}\text { There is no difference between ROE of Sukuk FinancingReject } \\
\text { Institutions and interest-based financing schemes of } \\
\text { conventional Financing Institutions }\end{array}$ & $t=-4.206, \mathrm{p}<0.05$ \\
\hline 3 & $\begin{array}{l}\text { Thereisnodifferencebetween ROCEofSukuk Financing In-Reject } \\
\text { situations and interest-based financing schemes of } \\
\text { conventional Financing Institutions }\end{array}$ & $t=-2.595, \mathrm{p}<0.05$ \\
\hline 4 & $\begin{array}{l}\text { There is no difference between the Net profit Margin ofReject } \\
\text { Sukuk Financing Institutions and interest-based financing } \\
\text { schemes of conventional Financial institutions. }\end{array}$ & $t=-2.506, \mathrm{p}<0.05$ \\
\hline
\end{tabular}

\section{Discussion}

The findings of the present study second most of the studies conducted previously in relation to considering the Islamic Financials as more profitable than that of the Conventional Financials. For example, the study conducted by Arslan-Ayaydin, Bejaoui, Dorsman, and Shahzad (2016) revealed that Islamic financials are in the efforts to be socially responsible while operating in accordance with religious principles such as prohibiting the use of interest and following the model of profit and loss sharing with their clients and thus generating more revenue. The findings of this study are in line with the findings of the present study, which reveal the Islamic Financial as more profitable along with the other determining factors such as religious principles and so on. Similarly, the findings of the study conducted by Iqbal and Mirakhor (2011) are also similar in the way that IBs and Islamic finance, in general, represent one of the fastest growing financial industries despite its relatively short history compared to CBs. Apart from the profitability ratio of the Islamic financials, the companies providing Islamic financials (labelling as Sukuk) following additional attractive factors. For example, exploring the difference between the Islamic financing and Conventional financing, Arslan- Ayaydin, Bejaoui, Dorsman, \& Shahzad (2016) found that "Transactions in Islamic Finance (IF) are guided by ethical, moral, and social considerations. Moreover, according to IF money should be used to create social value. With regard to these point of views, IF aligns with Socially Responsible Investing (SRI), which refers to the combination of social, environmental and ethical requirements when making 
financial investment decisions" (p. 187).

\section{Conclusion}

The above research provides an indication that Sukuk financing institutions are performing well in their respective domains as compared to traditional ones since all of their profitability indicators are statistically better than those of traditional financing institutions if Sukuk Financing is itself playing a part in such increase of profitability. A thorough analysis of firms should be conducted that would control the effects of various variables therein and hence exclusive effects could be captured. The findings reveal the Islamic Financials (Sukuk) to be a significantly high source of profitability for a company along with the other clients' catchy determinants such as religious principles, shariacompliant instruments, and interest (Riba) free financing.

\section{Recommendations}

Since the findings of the present study reveal as well as the reviewed literature demonstrates that Islamic Financials (Sukuk) is significantly high in terms of profitability for a company, companies are recommended to pay more attention to Islamic Sukuk in order to grab the attention of customers. Furthermore, the Islamic Financials (Sukuk) offers other instruments to catch the customers' attention such as religious principles, sharia-compliant instruments, and interest (Riba) free financing. From this perspective, the mentioned determinants fulfil the religious needs of customers.

\section{References}

Sarea, A.M., 2012. The level of compliance with AAOIFI accounting standards: evidence from Bahrain. International Management Review, 8(2), pp.27-32.

Al-Ajmi, J., Abo Hussain, H. and Al-Saleh, N., 2009. Clients of conventional and Islamic banks in Bahrain: How they choose which bank to patronize. International Journal of Social Economics, 36(11), pp.1086-1112.

Ali, A.E.E.S., 2014. The challenges of islamic trade finance in promoting SMES in IDB member countries (No. 1435-6).

Al-Salem, F.H., 2009. Islamic financial product innovation. International Journal of Islamic and Middle Eastern Finance and Management, 2(3), pp.187-200. 
Journal of Business Management and Economic Research, vol.3, issue.2, pp.26-41

Amin, H., Rahim Abdul Rahman, A., Laison Sondoh Jr, S. and Magdalene Chooi Hwa, A., 2011. Determinants of customers' intention to use Islamic personal financing: The case of Malaysian Islamic banks. Journal of Islamic Accounting and Business Research, 2(1), pp.22-42.

Arslan-Ayaydin, Ö. Bejaoui, M., Dorsman, A.B. and Shahzad, K., 2016. Islamic Finance versus Conventional Finance. In Energy and Finance (pp. 187-203). Springer, Cham.

Bley, J. and Kuehn, K., 2004. Conventional versus Islamic finance: student knowledge and perception in the United Arab Emirates. International journal of Islamic financial services, 5(4), pp.17-30.

Boslaugh, S., 2007. Secondary data sources for public health: A practical guide. Cambridge University Press.

Boslaugh, S., 2007. An introduction to secondary data analysis. Secondary data sources for public health: A practical guide, pp.2-10.

Derigs, U. and Marzban, S., 2008. Review and analysis of current Shariah-compliant equity screening practices. International Journal of Islamic and Middle Eastern Finance and Management, 1(4), pp.285-303.

Hanif, M., Tariq, M. and Tahir, A., 2012. Comparative performance study of conventional and Islamic banking in Pakistan. International Research Journal of Finance \& Economics, (83).

Heikal, M., Khaddafi, M. and Ummah, A., 2014. Influence analysis of return on assets (ROA), return on equity (ROE), net profit margin (NPM), debt to equity ratio (DER), and current ratio (CR), against corporate profit growth in automotive in Indonesia Stock Exchange. International Journal of Academic Research in Business and Social Sciences, 4(12), p.101.

Iqbal, Z. and Mirakhor, A., 2011. An introduction to Islamic finance: Theory and practice (Vol. 687). John Wiley \& Sons.

Islam, K.A., Alam, I. and Hossain, S.A., 2014. Examination of profitability between Islamic banks and conventional banks in Bangladesh: A comparative study. Research in Business and Management, 1(1), pp.78-89.

Jobst, A., 2007. The economics of Islamic finance and securitization (No. 7-117). International Monetary Fund. 
Economics, M.D.M., 2015. Relationship between capital, risk and efficiency. International Journal of Islamic and Middle Eastern Finance and Management, 8(2), pp.203-221.

Mollah, S. and Zaman, M., 2015. Shari'ah supervision, corporate governance and performance: Conventional vs. Islamic banks. Journal of Banking \& Finance, 58, pp.418-435.

Nazar, J.K., 2015. Regulatory and financial implications of Sukuk's legal challenges for sustainable Sukuk development in Islamic capital market. Ethics, Governance and Regulation in Islamic Finance, p.135.

Penman, S.H., 2016. The design of financial statements.

Rahman, M.L. and Banna, S.H., 2016. Liquidity Risk Management: A Comparative Study between Conventional and Islamic Banks in Bangladesh. Journal of Business and Technology (Dhaka), 10(2), pp.18-35.

Saiti, B., Bacha, O.I. and Masih, M., 2016. Testing the conventional and Islamic financial market contagion: evidence from wavelet analysis. Emerging Markets Finance and Trade, 52(8), pp.1832-1849.

Samad, A., 2004. Performance of Interest-free Islamic banks vis-à-vis Interest-based Conventional Banks of Bahrain. IIUM Journal of Economics and Management, 12(2), pp.1-15.

Sidlo, K., 2017. Sharia-compliant investments in infrastructure and development capital financing in DFID/CDC/PIDG geographies.

Uusmani, M.T. and Taqī 'Usmānī, M., 2002. An introduction to Islamic finance (Vol. 20). Brill.

Waemustafa, W. and Sukri, S., 2016. Systematic and unsystematic risk determinants of liquidity risk between Islamic and conventional banks. 